\title{
The Influence of Think Talk Write Model Implementation in Learning Theme Always Saving Energy
}

\author{
Anisa Hartani ${ }^{1}$, Sri Utaminingsih ${ }^{2}$, Suad $^{3}$ \\ \{201703030@std.umk.ac.id'1 , sri.utaminingsih@umk.ac.id², suad@umk.ac.id $\left.{ }^{3}\right\}$ \\ ${ }^{1,2,3}$ Faculty of Teaching and Education, Universitas Muria Kudus Gondang Manis PO. BOX 53 Bae, \\ Kudus, Central Java, Indonesia Phone (+62291) 438229, Fax (+62291)437198
}

\begin{abstract}
The research to determine the implementation of TTW model that has an impact in improving the quality of learning theme always save energy. This research is a quasi-experimental study with a population of fourth grade primary school students in the Sultan Agung Cluster and the research sample uses purposive sampling technique. Analysis of the data obtained using the t-test sig (2-tailed) is smaller than $\alpha=0.05$ $(0.000<0.05)$ so, $\mathrm{Ha}=$ accepted and $\mathrm{Ho}=$ rejected. The result of the research concluded that the application of the TTW model has an effect in improve the quality of learning theme always save energy based on the acquisition of pretest and posttest scores from the experimental and control classes. Improved the quality of learning getting score 0.450 in the experimental class with medium interpretation and 0.253 in the control class with low interpretation.
\end{abstract}

Keywords: Think Talk Write Model, Learning Quality.

\section{INTRODUCTION}

The 2013 curriculum is a combination of several subjects shortened in a theme in the implementation of learning. The integration of serval subjects intergrated in the theme has the effectiveness in changing, improving, and balancing the ability to think and act harmonized into three competencies, namely attitudes, skills, and knowledge (Murfiah, 2017) [1]. The 2013 curriculum has a learning approach called interactive thematic learning approach. Integrative thematic learning in the 2013 curriculum is learning that emphasizes student involvement in the learning process and direct student to be active in the learning process (Murtono, 2017: 176) [2]. The application of interactive thematic learning that is appropriate and in accordance with its proportions, can train student to gain direct experience in solving problems independently or individually from a variety of knowledge that has been learned. But in reality, the quality of interactive thematic learning in primary school is not optimal. There are still some students who are passive in implementing learning, afraid to express opinion, argue, and provide comment on a problem given by the teacher in the classroom. Student prefer to equate opinions with friend and other group and, less confident with each 
personal opinion when solving problem either in group, discussions, or independently. In addition, students with high abilities dominate learning and dare to express fearless opinions compared to students with medium and low abilities. Discrimination and not optimal implementation of thematic learning can have an impact on the low quality of learning. The low quality of learning is caused by the application of indicators of learning quality that have not been applied optimally to the process of teaching and learning activities. The application of indicators of the quality of learning is used as a benchmark to determine the direction and objectives of learning tobe quality. The reference of achieving optimal learning quality can be seen from the improvement of students mindset, student activities, teacher teaching skills, student learning outcomes, and all teaching components related to the teaching and learning process. A quality teaching component gives a good effect on students so that, independently and in groups can solve problems related to the surrounding environment.

Agree with the Depdiknas about the definition of operational learning quality, the quality of learning has a close relationship with the teaching component including teacher, student, curriculum, teaching material, facilities and infrastructure, as well as the learning system in producing a process that has an impact on optimal learning outcome and is appropriate application of existing curriculum objectives (Depdiknas, 2004) [3].The quality of learning theme two (Always Saving Energy) in primary school is low. Found a problem of lack of optimal quality of learning theme two (Always Saving Energy) in the Sultan Agung Cluster of Mejobo District fourth grade on the content of learning Indonesia Lenguage and Natural Science has a low average. The results of the pre-research conducted on Agustus 1, 2019 in theme two (Always Saving Energy) of low quality can be seen in the following table.

Table 1. Student Pre-Research Results Theme II

\begin{tabular}{|c|c|c|c|c|}
\hline No & School Name & Average & KKM & $\begin{array}{c}\text { The Number } \\
\text { of Students }\end{array}$ \\
\hline 1 & SD N 5 Mejobo & 63.2 & 70 & 20 \\
\hline 2 & SD IT AL-Kausar & 62.5 & 70 & 20 \\
\hline
\end{tabular}

[Source: Students Pre-Research Results, 2019]

Based on observations on August 1, 2019, the problem of the low quality of learning the theme two (Always Saving Energy) is caused by two factors, namely internal factors and external factors. Internal factors thet influence the low quality of learning are students feel difficulties and are not accustomed to description opinions both verbally and in writing, if faced with questions in the from of description. This can make it possible for some students to answer in the same language in describing the opinions of students with one another so that, it can be concluded that students are easily influenced by other peoples answers without thinking about the consequences of the truth. The second factor is that external factors are the most dominating factor and effect the low quality of student learning derived from teaching patterns and teacher learning in the classroom.

The pattern of teaching and learning carried out by the teacher in the process of teaching and learning activities, have not implemented model and method of learning that are effective in improving the quality of learning. Although it has implemented a collaborative learning method with peer tutor, in its application it has not been able to improve the quality of learning. Solution to overcome the problem of lack of quality learning in the Sultan Agung Cluster of Mejobo District by applying an innovative learning model that is adapted to the material and characteristic of student at school. Think talk write learning model can provide opportunities to improve the quality of learning and develop student thinking abilities to be improved individually or in group. In addition, the stages of the learning activities of the think 
talk write model give freedom to student to explore ideas and knowledge ore related to each students learning experience.

The learning model think talk write is a cooperative learning model that has stages of learning activities by way of thinking, speaking and writing that can make an impact in creating an atmosphere of learning fun, meaningful, social, democracy, enhance the activity of students in learning, increase participation and interest in learning, and improve students understanding and memory (Ardiansyah, 2013; Supraptinah, 2013) [4]. The result of the application of the TTW (Think Talk Write) model can have an influence in improving the quality of social studies learning in fourth grade primary school. Based on the results of the influence test data using the t-test obtained sig 2 -tailed $<\alpha(0,000<0,05)$, it can be concluded that $\mathrm{Ha}$ is accepted and Ho is rejected. Based on the data, proving that there is an influence of the use the TTW model in improving the quality of learing by increasing the quality of learning by 0,29 in low control category and 0,59 in the experimental class with a medium category so that the applicaton of the TTW model can provide benefits in improving the quality learning, able to invite student to be able like learning, explore student thoughts, express the result of thought, and make an impact on positive activities in learning (Nurlindasari and Mulyani, 2018; Yazid, 2012: 32) [5]. Based on the explanation of the research objectives, the title of the research was taken entitled "The Influenced of Think Talk Write Model in Learning Theme Always Saving Energy".

\section{METHOD}

This type of research is an experiment using a quasi experimental research design. Quasi experimental design is a research design that is used because researchers find it difficult to tightly control the entry of variables originating form outside even though they already have a dick group whereas, the design from is a non-equivalent control group design. Non-equivalent control group design has similarities with the pretest-posttest control design only, the difference lies in the taking of the experimental group and the control group thet is not randoms selected for the non-equivalent control group design. The description of the research design used is as follow (Sugiyono, 2015: 116) [6].

\begin{tabular}{|lcc|}
\hline O1 & $X$ & $O 2$ \\
\hline$O 3$ & & O4 \\
\hline
\end{tabular}

Fig 1. Research Design Non-equivalent Control Group Design

Description:

O1 $=$ Experiment Group Pretest

$\mathrm{X} \quad=$ Treatment of TTW Learning Model

$\mathrm{O} 2=$ Experiment Group Posttest

$\mathrm{O} 3=$ Pretest Control Group

$\mathrm{O} 4=$ Posttest Control Group

Experimental research was carried out in the fourth grade primary school of the Sultan Agung Cluster, Education and Youth Departement of Sport, Mejobo District. The research aims to determine the implementation of the TTW model influential in improving the quality of learning theme II in fourth grade by focusing on taking the contentsof learning Indonesia Language and Natural Sciences. The study population was all fourth grade students of the 
Sultan Agung Cluster, the sampling used a purposive sampling technique and two classes were used as research. Before selecting control and experiment classes, the data were tested for average similarity to find out the initial conditions of the two classes were not much different so, obtained class selection namely SD 5 Mejobo as an experimental class totaling twenty students and SD IT Al-Kausar as a contol class that there are twenty students. The researcher divided the research procedure into three stages including preparation, implementation and reporting. The research variables consist of independent, control, and dependent variables. The idependent variable in the research is the think talk write learning model. The dependent variable in the research is the quality of learning theme II (Always Saving Energy). The contol variables in the research are in the form of learning material, pretest and posttest question sheets, and the use of learning models.

Data collection techniques using test and documentation. The validity used in the research is the validity of expert judgment. The validity stage is carried out in three stages including (a) the researcher submits the validation sheet and the instrument to be used in the research to the validator, (b) the validator conducts the content validation of the test instrument, and (c) the validator states the instrument is valid then the instrument meet the content validation, and the instrument said valid if the assessment indicator meet the minimum value is quite valid (Azwar, 2017: 112) [7]. Data analysis in testing hypotheses in the research of the effect of implementing think talk write model in improving the quality of learning theme II (Always Save Energy) through prerequisite test including average similarity test, normality test, homogeneity test, hypothesis test, and N-gain test (Siregrar, 2018) [8].

\section{RESULTS AND DISCUSSION}

The process of data acquisition was done by giving a test twice in the experimental and control classes in the from of pretest and posttest. Pretest was given to students to know the initial ability of learning quality of theme II whereas, posttest was given to know the quality of learning after treatment was given. Meansurement of students initial abilities was done by ttest (independent test). The following table shows the results of the average similarity of two classes pretetst.

Table 2. Average Similarity Test Result for Independent Sampel Test

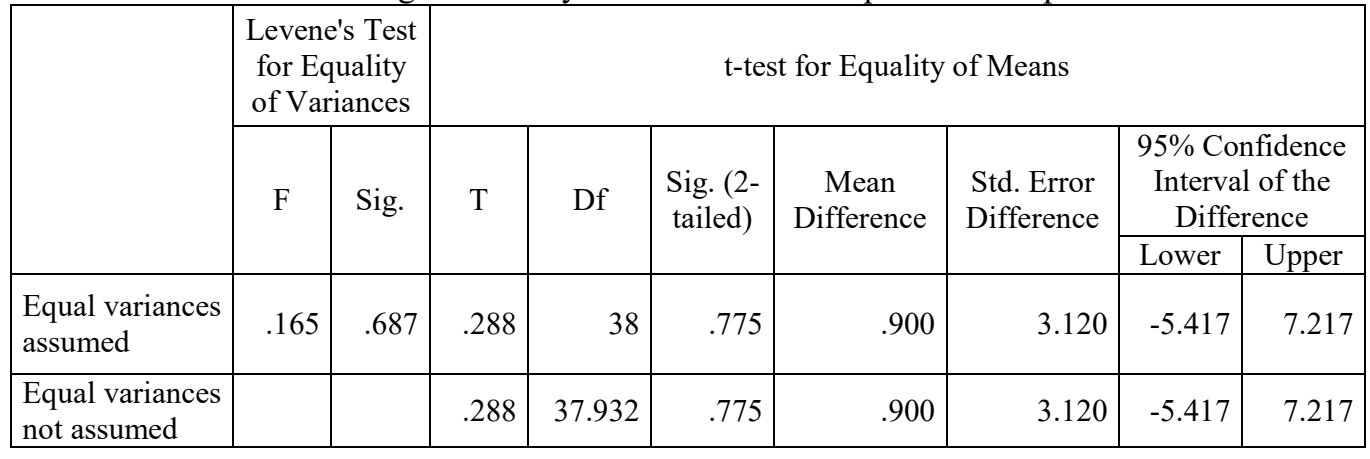

The results of the average similarity test using the t-test on results of students pretest scores showed that the quality of early learning in the control class an in the experimental class was relative same. Based on the results of statistical calculations the average value of the experimental and control classes obtained t-count of 0.288 and, the acquisition $\mathrm{df} n-2=40-$ 
$2=38$ and sig ( 2 tailed) of 0.775 . The results of the significance level in the sig (2-tailed) $t$ test table above, amounting to sig $0.775>\alpha=0.005$ then, in accordance with the provisions of sig $>\alpha$ conclude that $\mathrm{Ha}$ is accepted so, there is no difference in the average of the two classes so that it can be said to be two class experiment and control have the same initial ability. Furthermore, the results of the differences in pretest and posttest before and after the action of obtaining the data in the experimental and control classes are described in the table.

Table 3. Description of Analysis of Pretest and Posttest Results

\begin{tabular}{|l|c|c|c|c|c|}
\hline & N & Minimum & Maximum & Mean & Std. Deviation \\
\hline Pre-Test Eksperimental & 20 & 46 & 78 & 64.90 & 9.657 \\
\hline Post-Test Eksperimental & 20 & 64 & 94 & 80.70 & 8.591 \\
\hline Pre-Test Control & 20 & 46 & 78 & 64.00 & 10.073 \\
\hline Post-Test Control & 20 & 58 & 88 & 73.10 & 8.885 \\
\hline
\end{tabular}

Based on table 3 the experimental class pretest results obtained an average value of 64.90 with a minimum value of 46 and a maximum of 78 as well as, posttest value of the experimental class obtained an average value 80.70 with a minimum value of 64.00 with a minimum value of 46 and 78 whereas, the posttest value of the control class obtained an average of 73.10 with a minimum value of 58 and a maximum of 88 . Based on the description analysis table shows that there is an increase in the average quality of student learning on theme II between the two classes. The improving learning quality can be seen from the average pretest and posttest results of the control class and the experimental class. The improving learning quality in the experimental class is higher that the control class. Improving the quality of learning is illustrated through acomparison diagram of the results of the pretest and posttest in the experimental and control classes.

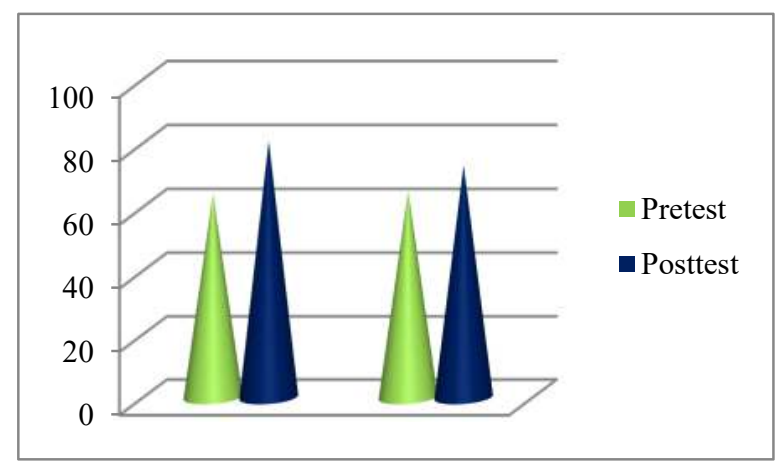

Fig 2. Comparison Diagram of Pretest dan Posttest Results

The results of the pretest in the control class obtained an average value of 64.00 and the posttest of the control class obtained an average of 73.10. From the of the pretest and posttest the control class experienced an average increase of 9.1. In the experimental class obtained an average pretetst score of 64.90 and posttest obtained an average of 80.70 . In the experimental class an average increase of 15.8. Futhermore, the results of the pretest and posttest data were tested for normality. Normality test is used to find out whether data is normally distributed or not. Testing of normally distributeddata is done by the kolmogrove-smirnov and shapiro-wilk. Data is normally distribute if it significance $>0,05$ but, if the data is siginificance $<0,05$ then 
the data is not normally distributed. Testing data using parametric statistics with the help of SPSS version 23.0. The normality data test results are explained in the following table.

Table 4. Normality Test Analysis Results

\begin{tabular}{|l|c|c|c|c|c|c|}
\hline \multirow{2}{*}{\multicolumn{1}{|c|}{ Kelas }} & \multicolumn{3}{|c|}{ Kolmogorov-Smirnov } & \multicolumn{3}{c|}{ Shapiro-Wilk } \\
\cline { 2 - 7 } & Statistic & Df & Sig. & Statistic & Df & Sig. \\
\hline Pre-Test Experimental (TTW) & .151 & 20 & $.200^{*}$ & .939 & 20 & .230 \\
\hline Post-Test Experimental (TTW) & .100 & 20 & $.200^{*}$ & .970 & 20 & .745 \\
\hline Pre-Test Control (Convensional) & .174 & 20 & .113 & .926 & 20 & .127 \\
\hline Post-Test Control (Convensional) & .131 & 20 & $.200^{*}$ & .951 & 20 & .387 \\
\hline
\end{tabular}

The results of the pretest and posttest normality tests of the experimental class obtained sig 0.200 in the kolmogrov-smirnov whereas in the shapiro-wilk they obtained sig 0.230 for the pretest and 0.745 form the posttest. In the control class normality test using kolmogrovsmirnov in pretest and posttest obtained sig of 0.113 and 0.200 while in thw shapiro-wilk test obtained sig 0.127 and 0.387 . Based on the provisions of the pretest and posttest results of the experimental and control classes in the normality test it appears that the results of the kolmogrov-smirnov and shapiro-wilk test obtained significance value $>0,05$ so, it was concluded that the data of the two classes were normality distributed. After the data is normally distributed homogeneity test is performed. Homogeneity test is used to find out homogeneous data or not. Homogeneity test using SPSS 23.0 with levene test.

Table 5. Pretest Homogeneity Test Results

\begin{tabular}{|c|c|c|c|}
\hline Levene Statistic & df1 & df2 & Sig. \\
\hline .165 & 1 & 38 & .687 \\
\hline
\end{tabular}

Based on table 5 explains that the homogeneity test results of pretest data obtained 0.687 significance. Obtaining a significance results of 0.687 explains that the pretest question data in the control and experimental groups have indentical or homogeneous variants. In addition to homogeneity tests on pretest data, homogeneity tests can be performed on posttest data. The results of homogeneity data analysis in the posttest data are explained in the following table.

Table 6. Posttest Homogeneity The Results

\begin{tabular}{|c|c|c|c|}
\hline Levene Statistic & $\mathrm{df} 1$ & $\mathrm{df} 2$ & Sig. \\
\hline .318 & 1 & 38 & .576 \\
\hline
\end{tabular}

In the results of table 6 the homogeneity test results of the posttest data of the experimental and control classes show the significance results of 0.567. Based on the acquisition of sig in the posttest concluded the data heve indentical or homogeneous variants with the provisions of $\operatorname{sig}>\alpha=0.05$. Hypothesis testing is used to determine the effect of the implementation of the TTW model in improving the quality of learning tested with the t-test formula. The basis for decision making on the t-test has aprovision thet if the data is significant the Ha is accepted and Ho is rejected with the results of the hypothesis test there is an effect of implementation of the TTW model in improving the quality of learning theme II. Conversely, if the data are not significant, $\mathrm{Ha}$ is rejected and Ho is accepted, the results of hypothesis test conclude that there is no significant effct on the implementation of the TTW model in improving the quality of learning theme II. T-test test data processing is performed with the help of SPSS program version 23.0. The following table tests the results of hypothesis testing using pairet sample test 
Table 7. Results of T-test Test Analysis

\begin{tabular}{|c|c|c|c|c|c|c|c|c|c|}
\hline & \multicolumn{5}{|c|}{ Paired Differences } & \multirow{3}{*}{$\mathrm{T}$} & \multirow{3}{*}{ Df } & \multirow{3}{*}{$\begin{array}{l}\text { Sig. (2. } \\
\text { tailed) }\end{array}$} \\
\hline & & \multirow[t]{2}{*}{ Mean } & \multirow{2}{*}{$\begin{array}{l}\text { Std. } \\
\text { Deviati } \\
\text { on }\end{array}$} & \multirow[t]{2}{*}{$\begin{array}{l}\text { Std. Error } \\
\text { Mean }\end{array}$} & \multicolumn{2}{|c|}{$\begin{array}{l}95 \% \text { Confidence } \\
\text { Interval of the } \\
\text { Difference }\end{array}$} & & & \\
\hline & & & & & Lower & Upper & & & \\
\hline Pair 1 & \begin{tabular}{|l} 
Pre-Test \\
Experimen - \\
Post-Test \\
Experimen \\
\end{tabular} & $\begin{array}{c}- \\
15.80 \\
0\end{array}$ & 10.360 & 2.317 & -20.649 & -10.951 & -6.821 & 19 & .000 \\
\hline Pair 2 & $\begin{array}{l}\text { Pre-Test Control } \\
\text { - Post-Test } \\
\text { Control } \\
\end{array}$ & $\begin{array}{c}- \\
9.100\end{array}$ & 7.269 & 1.625 & -12.502 & -5.698 & -5.599 & 19 & .000 \\
\hline
\end{tabular}

Based on the t-test results obtained a signicant level in pair 1 of 0.000 and pair 2 of 0.000 . From both pair 1 and pair 2 analyzes the results of sig 2 -tailed is smaller than $\alpha(0.000<0.05)$ $\mathrm{s} 0$ it can be concluded that there are differences in the average value between the two classes. Based on the results of pair 1 wich is used as a hypothesis test, it explains that the results of sig 2-tailed is $0.000<\alpha=0.05$. The results of the hypothesis test data using the t-test can be said that based on the results of sig 2-tailed pair 1 concludes that the data is significant then $\mathrm{Ha}$ is accepted and $\mathrm{Ho}=$ rejected. The results of improving quality of learning theme II in control and experimental classes can be seen based on the normalized gain test. The table of $\mathrm{N}$-gain test results is explained below.

Table 8. Pretest dan Posttest N-gain Test Results

\begin{tabular}{|l|c|c|c|c|}
\hline \multirow{2}{*}{ Kelas } & \multicolumn{2}{|c|}{ Average } & \multirow{2}{*}{ N-gain } & \multirow{2}{*}{ Interpretation } \\
\cline { 2 - 3 } & Pretest & Posttest & & \\
\hline Control Class & 64,00 & 73,10 & 0,25 & Low \\
\hline Experimental Class & 64,90 & 80,70 & 0,45 & Medium \\
\hline
\end{tabular}

The gain test results in table 8 explain that control class obtained 0.25 in the low category, with the gain score in the contol class les than 0,30 referring to the $\mathrm{N}$-gain category teble according to Hake $(0.25<0.30)$. In the experimental class the gain results are 0.45 in the medium category, with the experimental class gain results more than 0.30 referring to the $\mathrm{N}$ gain category table according to Hake $(0,45>0,30)$. Based on the results of the gain test it was concluded that there were differences in the quality of learning theme II on the experimental and control classes. Improving the quality of learning theme II between the experimental and control classes is higher than the experimental class control class. Based on the pretest and posttest data test in the experimental class with the implementation of the TTW model in its implementation it is more effective to improve the quality of learning. More details about improving the quality of learning are illustrated in the following diagram. 


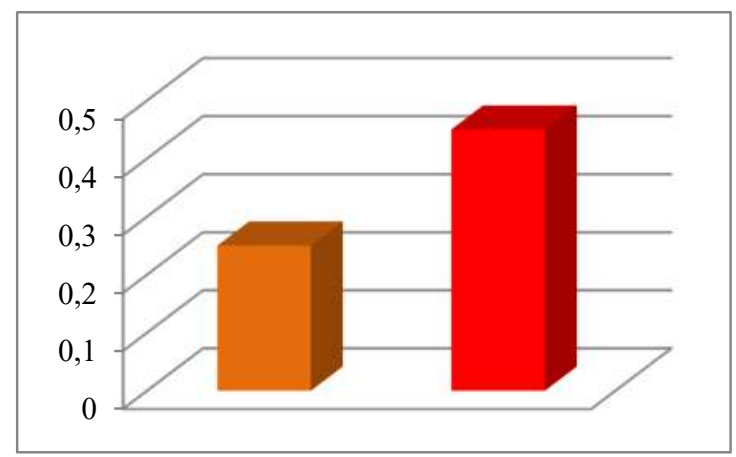

Fig 3. Diagram of Quality Improvement of Learning Theme II

Data analysis about the effect of implementing the TTW model in improving the quality of learning theme II is explained in table 7 using t-test test calculation. Based on the results of the t-test is known that the significance level og 0.000 is smaller than $\alpha=0.05$ with the concludion $\mathrm{Ha}=$ raccepted and $\mathrm{Ho}=$ rejected. In addition, it supported by the result of the average difference between the ekpsrimen and control classes. In experimental class the average pretest was 64.90 and the posttest 80.70 whereas, in the control class the average pretest was 64.00 and the posttest was 73.10 . From the data it can be seen that there are different treatments from the two classes that make a difference in the average quality of learning outcome of theme II fourth grade students of the Sultan Agung Cluster. Different treatments can be seen in the use of learning model between convetional model and TTW model. Based on the analisysis of influence test data, concluded that there is a significant influence of the use of models in improving the quality of learning on theme II between the use of the TTW model and conventional model. The use of the TTW learning model has a more significant influence in improving the quality of learning. Test for improving the quality of learning theme II fourth grade students can be calculatetd using the normalized gain test (Ngain). Based on the results of the gain test shows that the quality of learning has increased both in the experimental control classes. However, amore effective increase in learning theme II was seen from the results of the gain test in the experimental class. The results of the N-gain test in the experimental class amounted to 0.45 in medium category whereas, in the control class it was 0.25 in low category. Although the control class has improved the quality, seen from the average results of the increase in the pretest and posttest value of 64.00 and 73.10 however, the gain test results in the control class cannot be categorized that the control class has improved the quality if learning theme II based on the assessment the categoru table according to Hake. Therefore based on the results of data analysis, the use of the TTW model impementend in the experimental class is batter able to improve the quality of learning theme II (Always Save Energy). Strengthened by the opinions of Suprijono about the advantages of using the think talk write midel that is able todevelop problem solving skills, develop thinking skills, foster students interest with student (Suprijono, 2012: 215) [9].

Improving the quality of learning theme II using the TTW model is more effective and is able to have a significant impact on learning. In the experimental class the learning activities are carried out optimally so that, it effects the increase in students mindset to futher develop the ability to think, communicate, and interact between friends, teacher, and group. The improvement instudents mindset is seen when applying the satge of the TTW learning model 
implemented in experimental activities. The first stage of thinking the activities undertaken are students analyzing the problems contained in the worksheet through reading information. Then, students write important points in the reading using small notes related to the problems thet exist in worksheet. The second stage talks about the activities the teacher gives the assignment and students formulating the results of group answers, group presentations, making conclusions and reflecting on activities. From the application of the stages of the TTW learning model in the experimental class, giving an impact to students to be more active in participating in learning, there are no gaps in learning, students can interact well in one group to exchange information, and all students are anthusiastic to answer questions from the teacher without feeling afraid of being wrong.

The implementation of learning in the experimental class using the TTW midel is very helpful for improving the quality of student learning on theme II. Problems related to discrimination in learning can be minimazed and student learning opportunities are average without distinguishing high, medium, and low ability students. All students are given the opportunity toexpress their opinions based on the results of their thoughts through writing and orally. This can trigger the enthusiasm of students in accepting learning and competing to find the right solution of the problems that have been discussed. In the implementation of learning in the control class, experienced many differences compared to the implementation of learning in the experimental xlass. In the control class the learning process has not been able to make students active, there are still students who are silent and do not pay attention to the teacher in learning, fear of answering questions from the teacher, and discrimination of students learning abilities seen between high, medium, and low ability students. Although the teacher has mastered the material well and applied the learning method, but in its implementation there are still many students who are indifferent inparticipating in learning. This can trigger the learning process to become monotonous and passive because, students who have high abilities dominate much learning compared to student who have medium and low abilities. Seeing the difference between the use of TTW and conventional learning model, the quality of learning will increase if several indicators of learning quality are optimally applied in the learning process. The implementation of improving the quality of learning using data TTW model has a great influence in improving learning theme II.

Suppoorted by the results of previous studies, the application of the TTW model has an effect on improving the quality of learning as evidenced by the average learning outcomes of experimental class students higher than the average learning outcome in the control class that uses convensional learning model. As much as 54.25 in the first research experimental class and 40.07 in the control class in the first research explained that, the TTW learning model has an influence in improving the quality of learning seen from the indicator of the differenc in average learning outcomes of the two classes in the first study. Learning increases with a significance level of less than 5\% and an average of 47.12 in the second research control class and 92.12 in the experimental class in the second research then, the application of the TTW model has advanteges in developing the ability to analyze, ask and answer, write, and able to encourage students to think individually and in groups (Arisa, 2015; Rizal, 2018; Yanuarta , 2014) [10].

\section{CONCLUSION}

Based on the results of the 2-tailed significance t-test of $0.000<0.05$, it was concluded that there was a significant influence on the implementation of the TTW model in improving the quality of learning theme always saving energy in the fourth grade of the Sultan Agung 
Cluster. In the implementation of learning the experimental class learning activities carried out can influence the improvement of students midset to further develop the ability to think., communicate, and interact between friends, teachers, and groups. Improved learning quality can be seen from the results of the $\mathrm{N}$-gain test of 0.45 in the experimental class with medium interpretation and 0.25 in the control class with low interpretation. Therefore, the implementation of the use of the TTW model in teaching and learning activities has an effect on improving the quality of learning seen from the average results of student learning differences. In the experimental class of 64.90 the results of the pretest and posttest amounted to 80.70 while, in the control class of 64.00 in the pretest and 73.10 in the posttest.

\section{REFERENCES}

[1] Murfiah, Uum.: Teori Pembelajaran Terpadu di Sekolah Dasar. Bandung: Alfabeta s[2] Murtono.: Model-model Pembelajaran Inovatif. Ponorogo: Anggota IKAPI, 2017.

[3] Depdiknas.: Peningkatan Kualitas Pembelajaran. Jakarta: Depdiknas. Gadjah Mada, 2004.

[4] Ardiyansyah, Agus.: Meningkatkan Hasil Belajar Pada Materi Pokok Hidrokarbon Melalui Model Pembelajaran Kooperatif Tipe TTW Bermuatan Karakter Siswa Kelas X-4 SMA N 6 Banjarmasin. Vol. 1, hlm. 93-104. Jurnal Inovasi Pendidikan (2013).

[4] Supraptinah, Umi.: Eksperimentasi Model Pembelajaram Discovery Learning, Problem Based Learning, dan Think Talk Write dengan Pendekatan Saintifik Terhadap Kemampuan Pemecahan Masalah Matematika Ditinjau Dari Kemandirian Belajar. Jurnal Matematika. Vol. 10, hlm. 1138-1149. Jurnal Matematika (2015).

[5] Nurlindasari,: Elli dan Mulyani. Pengaruh Model Think Talk Write Terhadap Kemampuan Berpikir Kritis Mata Pelajaran IPS Kelas IV Sekolah Dasar. Vol. 7, hlm. 1106-1118. JPGSD (2018).

[6] Yazid, Ahmad.: Pengembangan Perangkat Pembelajaran Matematika Model Kooperatif dengan Strategi TTW Pada Materi Volume Bangun Ruang Sisi Datar. Vol. 1, hlm. 31-37. Jurnal Unnes (2012).

[7] Sugiyono.: Metode Penelitian Pendidikan Pendekatan Kuantitatif, Kualitatif dan R\&D. Bandung: Alfabeta, 2015.

[8] Azwar, Saifuddin.: Reliabelitas dan Validitas. Yogyakarta: Pustaka Pelajar, 2017.

[9] Siregar, Syofyan.: Metode Penelitian Kuantitatif Dilengkapi Perhitungan SPSS. Jakarta: Prenada Media Group, 2018.

[10] Suprijono, Agus.: Cooperatif Learning Teori Aplikasi Pakem. Yogyakarta: Pustaka Pelajr, 2012.

[11] Ariasa, Gede Jano, dkk.: Pengaruh Model TTW Berbantuan Media Gambar Terhadap Hasil Belajar Bahasa Indonesia Siswa Kelas IV. Vol. 1, hlm. 1-10. Jurnal PGSD Universitas Pendidikan Ganesha (2015).

[12] Rizal, Muhammad Syahrul.: Pengaruh Model Pembelajaran Tipe Think Talk Write (TTW) Terhadap Keaktifan Dalam Pembelajaran IPS Kelas V SDN 20 Kuok. Vol. 3, hlm. 1-9. Jurnal Basicedu (2018).

[13] Yanuarta, Lidya, dkk.: Penerapan Model Pembalajaran Kooperatif Tipe Think Talk Write dengan Teknik Talking Stick dalam Meningkatkan Karakter Dan Hasil Belajar IPA Biologi. Vol. 3, hlm. 69-78. Pancaran (2014). 